\title{
Screenwriting: Between Art and Craft
}

Patrick Cattrysse $^{1}$

Recibido: 20/01/2020

Aprobado por pares: 17/03/2020
Enviado a pares: 20/01/2020

Aceptado: $17 / 03 / 2020$

DOI: $10.5294 /$ pacla.2021.24.2.5

Para citar este artículo / to reference this article / para citar este artigo

Cattrysse, P. (2021). Screenwriting: Between Art and Craft. Palabra Clave, 24(2), e2425.

https://doi.org/10.5294/pacla.2021.24.2.5

\section{Abstract}

This paper discusses the teaching of screenwriting and storytelling in terms of art and craft. It argues that since Romanticism established itself in the $19^{\text {th }}$ century as the dominant Western view on art and culture, it has driven a wedge between people's notions of art and craft, promoting the former and demoting the latter. This rift has impeded the teaching of screenwriting and storytelling in general. Following this, art historians and sociologists of art have suggested developing a "third system of art," one that reintegrates the artist and the artisan, the art and craft-based values. This essay develops the basic tenets of a "technical approach" to the teaching of screenwriting. This technical approach sits in-between a Romantically biased "free-wheeling" approach and a mechanistic, "rule-based" approach. It is argued that a technical approach to screenwriting or storytelling could help materialize such a "third system of art" and benefit the practice, teaching, and study of screenwriting and storytelling.

\section{Keywords (Source: Unesco Thesaurus)}

Teaching; freedom of expression; rules; vocational training; academic teaching; academic art teaching; narration; film makers; filmmaking; romanticism; film studies.

$1 \triangle$ https://orcid.org/0000-0001-8705-9264. Universiteit Antwerpen, Université Libre de Bruxelles, Bélgica. patrick.cattrysse@uantwerpen.be 


\section{Escritura de guiones: entre el arte y la artesanía}

\section{Resumen}

En este artículo, se analiza la enseñanza de la escritura de guiones y de la narración en términos de arte y de artesanía. Se sostiene que desde que, en el siglo XIX, el Romanticismo se estableció como la visión occidental dominante del arte y la cultura, se ha abierto una brecha entre las nociones que tienen las personas sobre el arte y la artesanía, con lo cual se promueve el primero y se degrada la segunda. Esta brecha ha obstaculizado la enseñanza de la escritura de guiones y de la narración en general. En consecuencia, los historiadores del arte y los sociólogos del arte han sugerido desarrollar un "tercer sistema de arte", uno que reintegre al artista y al artesano y a los valores basados en el arte y la artesanía. Para este fin, se desarrollan los principios básicos de un "enfoque técnico" para la enseñanza de la escritura de guiones, el cual se encuentra en un punto medio entre un enfoque “espontáneo" con sesgos románticos y un enfoque mecanicista "basado en reglas". Por último, se argumenta que un enfoque técnico de la escritura de guiones o de la narración podría ayudar a materializar ese "tercer sistema de arte" y a beneficiar la práctica, la enseñanza y el estudio de la escritura de guiones y de la narración.

\section{Palabras clave (Fuente: tesauro de la Unesco)}

Enseñanza; libertad de expresión; reglas; enseñanza académica; enseñanza académica de arte; narrativa; realizador cinematográfico; cineasta; director de cine; estudios de cine. 


\section{Escrita de roteiros: entre arte e artesanato}

\section{Resumo}

Neste artigo, é analisado o ensino da escrita de roteiros e da narrativa em termos de arte e artesanato. Argumenta-se que, desde que o Romantismo foi estabelecido como a visão ocidental dominante da arte e da cultura no século XIX, abriu-se uma lacuna entre as noções que as pessoas têm sobre a arte e o artesanato; com isso, é promovido o primeiro e degradado o segundo. Essa brecha impede o ensino da escrita de roteiros e da narrativa em geral. Em consequência, os historiadores da arte e os sociólogos da arte sugerem desenvolver um "terceiro sistema de arte", em que reintegre o artista e o artesão, bem como os valores baseados na arte e no artesanato. Para isso, foram desenvolvidos os princípios básicos de uma "abordagem técnica” para o ensino da escrita de roteiros, o que está em um ponto médio entre uma abordagem espontânea, com vieses românticos, e uma abordagem mecanicista, baseada em regras. Por último, argumenta-se que uma abordagem técnica da escrita de roteiros ou de narrativas poderia ajudar a materializar o "terceiro sistema de arte" e a beneficiar a prática, o ensino e o estudo da escrita de roteiros e da narrativa.

\section{Plavras-chave (Fonte: tesauro da Unesco)}

Ensino; liberdade de expressão; regras; ensino acadêmico; ensino acadêmico de arte; narrativa; realizador cinematográfico; cineasta; diretor de cinema; estudos de cinema. 


\section{Introduction}

This paper is addressed to screenwriting teachers and beginners first, but it may also be of interest to whoever is involved in the study and practice of writing stories. The title of this essay rekindles a topic that has been debated at several recent SRN ${ }^{2}$ conferences: "Screenwriting: Between Artistic Freedom and Norms" (2016), "Screen Narratives: Order and Chaos" (2019), and "Pushing Boundaries" (2020). The tensions suggested between artistic freedom and rules, chaos and order or boundaries reflect current Western views on art as high art, i.e., free from constraints, and therefore as distinct from and superior to craft. Many Western ${ }^{3}$ laypeople, including academics working outside the art worlds, still believe this idea of art to be universal, even though art historians and sociologists of art have long shown, rather convincingly, that it is a more recent Western invention (see, e.g., Kristeller, 1951; Sawyer, 2006, p. 5ff.; Shiner, 2001).

Accordingly, this paper is divided into five sections. Section one briefly sketches how a more comprehensive "pre-modern" view on art, which included craft, evolved into a narrower "modern" one, which redefined the concept as "fine art" and expelled craft from its territory. This paradigm shift resulted in the development of two different value systems. Scholars have given them other names (see below). I hereafter label them as the Romantic and Classicist value systems. Whereas the Romantic value system defines and appreciates artwork as fine art and depreciates other cultural practices and products as craft, the Classicist value system allows valuing craftworks on its own terms. Section two describes some of the core features of this Classicist value system. Before moving on, section three gives some caveats to the reader who might be opposed to binary categorizations: The Romantic and Classicist value systems are conceived as "probabilistic" categories. That is to say, they allow for graded category-membership and category-overlap, which explains how and why scholars have already speculated about a possible "third system of art." Section four looks into some of these proposals and, finally, section five suggests that a "technical" ap-

2 SRN stands for Screenwriters Research Network.

3 By “Western," I mean generally Europe, the Americas, and Australia. 
proach to screenwriting or story writing could help materialize such a third system and offer several advantages.

\section{A Romantic definition of "art"}

There are many definitions of art, even if one considers only Western views on Western art. However, sociologists of art and art historians agree that our current Western notion of art is mainly a European invention that is barely two hundred years old (see Kristeller, 1951; Mattick, 2003, p. 24; Sawyer, 2006, p. 12; Shiner, 2001, p. 3). They argue that a paradigm shift occurred gradually and replaced an old concept of art that lasted over two thousand years. Different historians have used other names to discuss this paradigm shift. ${ }^{4}$ Some critics trace anticipations of this new concept of art back to the late 1400s in the Italian Renaissance, when the activities of a painter, sculptor, or architect were considered as radically different from manual trades and achieved the dignity of "liberal" arts (Becker, 2008, pp. 353-354; Moulin, 1978, pp. 241-242; Shiner, 2001, p. 12). The artist is no longer an artisan, but a creator, a sort of "alter deus free from ordinary norms" (Becker, 2008, p. 353).

When in the eighteenth century the first industrial revolution sets in, the artistic product is defined as hand-made and unique, in opposition to the industrial products, which are machine-made, mass-produced, and identical. The question remains whether artistic creation is about perspiration or inspiration, whether it represents an active, free-willed, and intentional process or conversely results from unconscious and uncontrolled impulses. Either way, artistic creation is seen as an individual rather than as a collective expression of human emotions and cultural values. The result is Original with a capital $\mathrm{O}$ and innovating. Art is created out of nothing and is pure, i.e., not spoiled by antecedents or outside influences.

4 See, e.g., Lotman (1977), who distinguishes between the old and the new as an aesthetics of identity and an aesthetics of opposition, or Bourdieu (1998) who distinguishes between an aesthetics of continuity and an aesthetics of discontinuity. Abrams (1989, p. 140) speaks of a disinterested "contemplation" model that replaced a purposeful "construction" model, and some creativity scholars study similar judgmental patterns in terms of Rationalism and Romanticism (see, e.g., Sawyer, 2006, p. 15ff.). 
Artists, contrary to craftspeople, also remove the utilitarian from the artwork. Théophile Gautier coins the phrase "l'art pour l'art" in his 1835 novel, Mademoiselle de Maupin, and elsewhere in Europe artists pick up the slogan "art for art's sake". An artwork serves no other purpose than its own. Also, artworks obtain their value from being made by exceptionally gifted individuals, which evokes the notion of a "Genius-Auteur," who distinguishes himself from the ordinary people and justifies authorial glorification. The Artist with a capital A deserves and requires total freedom. Freedom means individual and self-oriented freedom. He (rather than she) stands above the rules and eventually above society. Rules either refer to what everyone else does or what everyone else should do. In either case, they dilute artistic value. Rules suggest deterministic features, which preclude difference and uniqueness. They force the artist into a submissive rather than an active mode and thus take away artistic freedom. Since rules are supposed to propagate tradition or convention, they go against innovation and originality. Consequently, rules represent a deficiency that "real" artists must overcome.

Scholars agree that this new, modern concept of art was consolidated in the eighteenth century (Kristeller, 1951, p. 496; Mattick, 2003, p. 8; Shiner, 2001, p. 3). Nineteenth-century artists even protect rarity and give social and economic value to the symbolic goods they produce. Art historians and sociologists of art also agree that although resistance against values of the Romantic ideology goes back to the Renaissance, Romanticism has continued to prevail among Western laypeople, including academics working in fields other than the arts ever since the early nineteenth century (Clowney, 2008; Sawyer, 2006, p. 17; Shiner, 2001, p. 7; Weiner, 2000, pp. 112-113). Moreover, Shiner points out that

Like so much else that emerged from the Enlightenment, the European idea of fine art was believed to be universal, and European and [North-]American armies, missionaries, entrepreneurs, and intellectuals have been doing their best to make it so ever since. $(2001, \text { p. } 3)^{5}$

5 See also Weiner (2000, pp. 112-113) and Sawyer (2006, p. 11) on globalization as the colonizing exportation of Western values across the planet. 
The relevance of this paradigm shift for the topic of this essay is described in great detail in Larry Shiner's The Invention of Art (2001). In short, it slowly but surely redefined the old and broader concept of art, which had lasted for over two thousand years, in a new narrower sense as "fine" or "high" art. Whereas the pre-modern concept of art included craft, the modern idea of (fine) "art" excludes craft from the art worlds (Shiner, 2001, pp. 5-10). In Antiquity, the Latin word "ars" like the Greek "techne" referred to the ability to make a valuable product of skilled work (Clowney, 2008; Shiner, 2001, p. 19; Weiner, 2000, p. 36). An artist was an artisan, and art included craftmanship. There was actually no proper Greek or Latin word for our modern Western concept of "artist." Even centuries later, when he was writing about Renaissance painters, sculptors, and architects, the Italian painter and architect Giorgio Vasari used the term "artifice," "artificer" (Shiner, 2001, p. 40), which signified artist/artisan.

Needless to say, the installation of this modern idea of art came with a whole array of far-going intellectual, socio-cultural, political, and economic changes, which took more than three centuries. It involved most notably the re-compartmentalization of practices, practitioners, audiences, and mediating institutions along the dividing line of "fine" art versus craft. During the process, the "new" Romantic view promoted the former and demoted the latter. To add to the confusion, after nineteenth-century usage dropped the adjective "fine" and spoke only of art versus craft or art versus entertainment (Shiner, 2001, p. 5).

\section{A Classicist definition of craftmanship}

If the Romantic view on art as "high" art and as separate from craft represents a recent Western invention, so does the view on craftwork as distinct from and as inferior to (fine) art. Once again, multiple definitions circulate, but many scholars agree to define "craftsmanship" as the ability to make or perform something useful (see, e.g., Becker, 1982, p. 272ff.; Shiner, 2001, pp. 3334). Consequently, if craftmanship is depreciated on the Romantic view, it is appreciated from a different set of values, which I hereafter call the Classicist value system. I call it the "Classicist" value system because it shares many similarities with the pre-Romantic art/artisanship system. I hereaf- 
ter list some typical features. Following the working definition, it first and foremost values a work in instrumental terms, i.e., based on a previously agreed-upon external purpose (e.g., accuracy, efficiency, performance, reliability) (Becker, 1982, pp. 273-275). Virtuoso skills (more or less difficult to do) and grace (e.g., aesthetics, beauty) may come in second.

Consequently, various features representing values per se in the Romantic ideology are assessed as means that serve the purpose in the Classicist value system. For example, uniqueness, originality, and difference are not valuable per se, nor are mass-production and sameness intrinsically negative features. ${ }^{6}$ The value of these features depends on how well they achieve their pre-set goal. The same argument applies to change versus maintenance. On this view, tradition is not intrinsically inferior to innovation. One does not change a winning team, nor does one fix what is not broken. These sayings suggest that generally speaking, traditions, standards, conventions, and rules have formed for a reason. They translate what is understood to be good practice. In other words, there are good reasons to stick to the rules and to comply with the convention.

If that is the case, someone wanting to deviate from convention or bend or break the rules should have a good reason to do so too. Therefore, breaking the rules for the sake of breaking them or deviating from convention just for the sake of deviating from it is not considered "original," nor does it suggest "freedom"; rather, it is seen as a mistake or as a sign of incompetence. The Classicist view does not imply that one holds onto tradition no matter what. Good practices last as long as the purpose of the work and the environment remain the same. If either one changes, standards, conventions, and rules must change with them. At the risk of becoming repetitious, following or not following rules, standards and conventions is neither good nor bad in itself; that judgment depends, again, on how well they serve the end-purpose of the work.

The above brings us to a second critical value in the Classicist value system: competence or virtuoso skills, the understanding that some things

6 Some manufacturers pride themselves on their product being the same all over the world (e.g., McDonald's, Coca-Cola). 
are more difficult to make than others, which is a non-issue in the Romantic value system. Since the artwork maker is assumed to be a Genius-Auteur, competence is taken for granted, and concern focuses primarily on (individual and self-oriented) freedom. The Classicist value system reverses that point of view: freedom is taken for granted, but competence or skills are questioned. If someone asks me if I can draw a perfect circle, the question is not whether I am allowed to draw a perfect circle but whether I am capable of drawing one. Thus, from the Classicist view, rules, standards, and physical or mental constraints are not seen as inhibiting freedom but as helping tools - like the pole used to walk on a tightrope-, or as challenges that defy skills (e.g., the bar raised at two meters in high jump). Competence also refers to skills one can teach and learn; hence the expression: "practice makes perfect."

Conversely, Romantically biased teachers who must teach art as an inborn, mysterious, or transcendent talent find themselves in the curious situation of having to teach the unteachable (Kristeller, 1951, p. 498). The Classicist view does not ignore innate talents but acknowledges that their presence or absence may enhance or inhibit teaching and learning processes. Since competence and achieving a pre-set goal come first, priority is not intrinsically superior to posteriority. ${ }^{7}$ If, one after the other, five athletes jump over that two meters high bar, the last one jumping is appreciated as much as the first. Finally, concerning the makers or performers, since a Classicist evaluation focuses on purpose first, individual authorial self-expression is a non-issue. Hence, the question of whether the work was made by one or more people or by a machine is irrelevant unless it impacts use. Use generally means socially embedded use. Hence, use connects (craft)work to society, whereas the Romantic view on (high) art does not so much remove artworks from society as displace them into separate, dedicated places, such as museums, theatres, libraries, or art galleries, where they are put on display to be contemplated on their own terms.

7 For a discussion on how this Romantic bias has impacted translation, adaptation, intertextuality and influence studies, see Cattrysse (2020). 


\section{Probabilistic categories}

Before moving on, I point to three caveats. Firstly, the Romantic and Classicist value systems represent probabilistic categories. Theories of categorization distinguish between the more recent probabilistic categories (e.g., prototype theory, exemplar theory) - I also refer to Wittgenstein's notion of "family resemblance"-and the classic Aristotelian all-or-nothing categories (Conradie et al., 2017; Goldstone et al., 2018; Minda, 2015, pp. 7477; Shepard, 1987). Probabilistic categories consist of multiple features, which allow for graded category-membership and category-overlap. Consequently, some members may be more typical of their category than others, and one category may display features that also appear in another category.

The binary distinction between a Romantic bias and a Classicist bias is not designed to divide two value systems in black and white. Instead, it helps describe and explain intermediate grey zones that sit in between the two extremes, which accounts for how some prior art and creativity scholars had already adopted an intermediate point of view and speculated about the possible emergence of "a third system of the arts," one that somehow preserves and combines the "best features" of both value systems (Clowney, 2008; Shiner, 2001, p. 225ff.). I hereafter argue that a "technical” approach to the study, teaching, and learning of screenwriting could help materialize such "third art system."

Secondly, as their names suggest, both the Romantic and Classicist value systems refer to judgmental patterns, i.e., values assigned by subjects to objects. Thus, two people may value the same work differently if they look at it through a Romantic or a Classicist lens. Moreover, one person may value the formal and content-based restrictions of a work (e.g., a sonnet) positively (e.g., in terms of competence) in the morning, yet value similar features (e.g., the three-act structure of a Hollywood movie) negatively (e.g., in terms of a lack of artistic freedom) in the afternoon; and that same person may not even be aware of its inconsistent use of double standards.

Finally, the examples of the sonnet or the Hollywood movie, as opposed to free verse poetry or experimental cinema, for example, suggest 
that works may exhibit intrinsic features that invite more or less clearly to a Romantic or a Classicist reading.

\section{A third system of art and craftsmanship?}

The paradigm shift that started in the late 1400s and led to the Romantic value system triggered at once a parallel tradition of resistance that persists until this day. In other words, the struggle between proponents and opponents of a split between (fine) art and craft is still ongoing. Some critics have argued that the resistance against the Romantic value system is growing stronger and that under the influence of this resistance, what they call the "modern art system" is changing (Clowney, 2008; Shiner, 2001, p. 307). However, the direction of these changes remains an open question.

Shiner (2001, pp. 306-307) speculates about the possible emergence of a "third system of art," one that would at once preserve and combine the best features of the Classicist and Romantic value systems, i.e., one that reunites art and craft, the artist and the artisan, the aesthetic and the purposeful, the genius and the rule, the expressive and the skilled, freedom and service. Thus, it would evaluate art and craftworks according to a combination of features taken from both value systems. However, given that it took the Romantic value system several hundred years to develop, Shiner acknowledges that establishing a third system of art that includes craft is likely to take a long time.

David Clowney (2008) concurs with Shiner that the Romantic value system remains totalitarian and powerful today, and he repeats that a change in the (dominant) conception of art would also require a broader change in the organization of society. The fine art system may well pretend to exist and function in an autonomous bubble outside society, but its existence and meaning depend very much on the societal relations it denies (see, e.g., Mattick, 2003). Clowney reiterates the question of whether the resistance against the fine art system is getting the upper hand or whether, on the contrary, the expansionist assimilation strategies of the latter continue to prevail. He seems less optimistic than Shiner with regards to the installation of a third system of art. When practitioners of the exiled fields of pop art, 
craft, or entertainment manage to earn the honorific title of "fine art," they seem to succeed more by replicating the fine art system's dynamics (e.g., by stripping utility from their works and putting it on display for disinterested contemplation) than by resisting them. On the other hand, Clowney suggests that these assimilation strategies entail changes inside the Romantic value system, for example, to the extent that features such as functionality, skill, and entertainment value are no longer automatically seen as diminishing aesthetic value.

\section{A technical approach to screenwriting}

Pending the end-game of the battle between the pre-modern and the modern system of art, I hereafter modestly argue that a "technical" approach to screenwriting may help materialize Shiner's (2008) and Clowney's (2008) "third system of art." The word "technical" rekindles the aforementioned Greek "techne," signifying both art and artisanship. When dealing with the study and practice of screenwriting, it suggests talking about "techniques" or tools instead of rules. Examples of tools or techniques ${ }^{8}$ are a hammer in carpentry, a tennis racket or a backhand in tennis, a protagonist or a three-act structure in screenwriting or storytelling. A technical approach is not uncommon in discourse about other art forms such as music or painting, and some teachers and analysts may already apply it to screenwriting as well, albeit implicitly. A technical approach combines both the Classicist and Romantic value system's key features and offers several advantages.

\section{Competence before freedom}

To talk about tools instead of rules shifts the focus from the concept of freedom to that of competence. Advice given in terms of tools instead of rules helps avoid the Romantic reflex of ignoring the advice and breaking or bending the rule merely for the sake of breaking or bending it. ${ }^{9}$ Advice given in terms of tools that remain available in a toolkit removes the threat to freedom - everyone is free to use a tool or not—and redirects the question

8 For the sake of my argument, I consider tools (e.g., hammer, tennis racket) or techniques (e.g., backhand, forehand, suspense, surprise) as members of the same category.

9 Note that breaking a rule just for the sake of breaking it is as unfree as slavishly following that rule. 
towards the skilled use of these tools. Consider the following common student questions:

\section{- Student:}

A. Can I write a story with more than one protagonist?

B. Can I write a story that does not fit the three-act structure?

Typically, these questions are Romantically biased, i.e., they express concern about a lack of freedom, not a lack of competence. In other words, the phrasing "Can I" refers to "Am I allowed to." A technical approach takes freedom for granted but questions competence. Hence, "Can I" is understood as "Am I capable" A teacher has, therefore, at least two answers to these questions:

- Teacher:

- Romantic answer (referring to freedom): "Of course you can."

- Classicist answer (referring to competence): "Can you?”

\section{Teaching and learning}

A focus on skills raises questions about the ease or difficulty of performing a task. Practices are qualified as more or less complicated by people who experience difficulties performing that task according to some pre-set agreed-upon standards. In this view, highly talented people may find it more challenging to teach when everything is accessible in their eyes. The awareness of ease or difficulty ushers screenwriting back into the realm of the teachable and the learnable. More difficult practices require more talents and more training; the opposite is true for less complicated practices.

A focus on competence points to the significant and little-studied distinction between how people write and how they learn how to write stories. ${ }^{10}$ Insights into the latter process open the door to the study and

10 How often have (screen)writing teachers been asked if they (also) write? The question confuses the skills required to write with those required to teach how to write; two interrelated, partly overlapping but distinct categories. 
development of step-by-step teaching and learning paths, and an empirically and theoretically founded didactics applied to screenwriting and storytelling. Good examples exist in other art forms, such as music manuals and music classes. To start such a process, one must stop the Romantically biased belief that one cannot teach or learn how to write stories. Note that a technical approach does not ignore the relevance of inborn talents. It is understood that every normally gifted person can learn how to ride a bike but not how to win the Tour de France. Everyone can learn how to play tennis but not how to win at Wimbledon. The same argument applies to writing stories.

\section{An instrumental view}

Tools represent means to achieve goals. Consequently, a technical approach installs an instrumental view. If tools serve a purpose, it is purpose, not freedom, that motivates users to (de)select the tool. That is why it makes sense for a Romantic view to reject utilitarianism. Following this, using the most obvious tool for a purpose does not need clarification, while not using it does. If I want to hit a nail in the wall, I can use a hammer, but I could also decide to use my shoe, and if I were desperate to be original, I could even decide to use my hand. Needless to say, choosing the hammer would offer the most sensible choice and would not require justification. Choosing my shoe might, since it is clearly a less practical choice, and opting for my hand is likely to be seen as too crazy to be taken seriously. However obvious this sounds in the world of craft, it is not in the world of art. The Romantic bias makes it so that instrumental thinking about storytelling and narrative techniques remains uncommon. Compare the following common student question $\mathrm{C}$ with the odd question $\mathrm{D}$ :

- $\quad$ Student:

C.: Should I always use a three-act structure to write a story?

D.: Should I always use a hammer to hit a nail in the wall?

- Teacher:

Romantic answer (referring to freedom): "Of course not."

Classicist answer (referring to use): "Why not?" 
If practices are seen as tools that serve a clear purpose, the questions become rhetorical. If practices are not seen as tools, purpose evaporates and advised practices become blind rules that merely inhibit freedom. In that case, we are back to square one: all it takes to be free and original is to break, bend or ignore the rule.

Finally, to conceive of some practice in terms of tools that serve a purpose allows for a two-layered analysis of that practice: at one level, the assessment concerns the more or less appropriate (de)selection of the tool, and at another level, it focuses on the more or less efficient application of the tool. If I choose a hammer to hit a nail in the wall, picking up the hammer does not guarantee that the nail will end up in the wall. Being an amateur, chances are I hit the fingers that hold the nail more often than the nail, and being an amateur, I am likely to blame the hammer and throw it away instead of blaming my incompetent use of it. Consequently, a more experienced hammer user is likely to suggest using the hammer more efficiently rather than throwing it away.

Similarly, a Romantically biased critic may complain about the predictable three-act structure of a story and suggest that the writer throws it away and "try something else." A technical or Classicist analysis will avoid throwing the proverbial baby out with the bathwater and split the analysis into two parts: first, verifying the appropriateness of the selected tool - in this case, the three-act structure - and then assessing the efficiency of its application. If it is understood that a well-written three-act structure remains invisible to the reader/viewer to allow the latter to become and stay involved in the story without noticing how it is told, one may assume that it was badly written since it drew the attention of the Romantic critic. Hence, before throwing it away altogether, one may advise the writer to rewrite the three-act structure more efficiently.

\section{Romantic values}

One should not confuse a technical approach with a mechanistic one. A mechanistic approach considers a practice as the mere application of a trick that automatically produces a guaranteed effect: you push the button and 
the light goes on, press the button again, and the light goes out. A mechanistic view deals with fully determinist, predictable processes and is therefore useless when considering complex, highly unpredictable practices such as writing stories.

On the other hand, a technical approach leaves a gap between the appropriateness of the selected tool and the efficiency of its application. In other words, the appropriate selection of a tool does not guarantee the efficient application of that tool. As indicated above, having chosen a hammer does not guarantee that the nail will end up in the wall. It is not because I have some rhetorical tools in my narrative toolkit that audience involvement is guaranteed.

Consequently, the one tool-many applications approach leaves space for some Romantic values such as (degrees of) variation, innovation, and unpredictability. The latter is often experienced as freedom or indeterminism, even though it actually results from randomness. Moreover, a technical approach does not suggest that only one application would be efficient.

Finally, this two-layered approach allows for a more "zoomed-out" perspective on the world, which might reveal more universal or widespread patterns at a more abstract category-level, and a more "zoomed-in" or localized perspective, which at the more concrete category-member level studies ad hoc or hic et nunc implementations of tools or strategies, revealing patterns of cultural and historical variation. For example, a protagonist, dramatic goal, and convincing "or else"-factor may represent universal strategies, but their implementation in specific narratives may show patterned cultural and historical variations. Whereas Western culture may opt more for individual and active protagonists, who take responsibility for their personal actions, Eastern cultures may prefer implementing these tools in terms of efficient collective re-action to outward forces that threaten the group's cohesion (see, e.g., Nisbett, 2005). ${ }^{11}$

11 For an introduction into this line of thinking, see Cattrysse $(2016,2017)$. 


\section{Conclusions}

A "technical approach" holds the middle between a deterministic rule-based view and a freewheeling "anything-goes" approach. As such, it is likely to disappoint both the mechanistic and the Romantic view on story writing. The mechanistic critic may call the technical approach useless since applying techniques does not offer guarantees. Conversely, the Romantic may equally feel disappointed because demystifying storytelling in terms of techniques reveals the magician's conjuring tricks: it takes away the magic.

In the meantime, art historians and sociologists like Larry Shiner, David Clowney, and Howard Becker show that slowly but surely, a "third system of art" is in the making: craftworks become art and vice versa. Yet another academic area where art and craft worlds clash, compromise, and merge is creativity studies. Creativity studies emerged in the 1950s and have since evolved into a full-fledged academic discipline covering both the art and non-art worlds (Sawyer, 2006; Weiner, 2000). Researchers often agree on a standard definition of "creativity" as the ability to produce something novel that is recognized as..., and then various qualifiers may follow such as "useful," "appropriate," or "valuable" (Lubart, 2018, p. 3; Runco \& Jaeger, 2012; Sawyer, 2006, p. 27; Walia, 2019, p. 2). What is interesting with respect to this paper is that, more often than not, creativity scholars understand "art" as "fine art" and, in accordance with Shiner's (2001) findings, adhere to Gautier's "art for art's sake." They choose a more or less utilitarian qualifier depending on whether their analytical focus includes or excludes art. Hence, innovation is expected to be appropriate or useful if it concerns business, politics, science, or everyday life.

Conversely, scholars go for the semantically wider, less utilitarian "valuable" when creativity (also) concerns art. Therefore, creativity studies offer an interesting arena where freedom and innovation for the sake of innovation do battle with utilitarianism both in and outside the artworlds. Even though Romantics may make mystifying claims about creativity, a technical approach is very common in creativity workshops. I refer, for example, to exercises in brainstorming, divergent and convergent thinking, etc. Once it is understood that the "art for art's sake" mantra is either naïve 
or hypocritical, ${ }^{12}$ one may understand creativity as purposeful innovation, i.e., as a practice that aims at innovative problem-solving. Hence, the question of how creativity studies may help marry Romantic art-thinking with craft-thinking deserves a separate study.

\section{References}

Abrams, M. H. (1989). Doing Things with Texts: Essays in Criticism and Critical Theory. W.W. Norton \& Company.

Becker, H. S. (1982). Art Worlds. University of California Press.

Becker, H. S. (2008). Art Worlds. 25th Anniversary Edition. Updated and Expanded. University of California Press. https://doi. org/10.1525/9780520934870-005

Bourdieu, P. (1998). Les règles de l'art. Genèse et structure du champ littéraire. Éditions du Seuil.

Cattrysse, P. (2016). Cultural dimensions and an intercultural study of narratorial behavior. The Journal of Internationalization and Localization, 3(2), 113-132. https://doi.org/10.1075/jial.3.2.01cat

Cattrysse, P. (2017). Cultural Dimensions and a Cultural Study of Screenwriting. In Transcultural Screenwriting. Telling Stories for a Global World (pp. 8-27). Cambridge Scholars Publishing.

Cattrysse, P. (2020). Translation and Adaptation Studies: More Interdisciplinary Reflections. TRR: Traduction, Terminologie, Rédaction. https://doi.org/10.7202/1071147ar

12 See, e.g., the Mexican painter Diego Rivera (1932) predicting already in the 1930s how the "art for art's sake" theory would further divide the rich from the poor, and turn art into a currency-like trading tool for the super-rich to avoid taxes and inflation. 
Clowney, D. (2008). A Third System of the Arts? An Exploration of Some Ideas from Larry Shiner's The Invention of Art: A Cultural History. Contemporary Aesthetics, 2(6).

Conradie, W., Frittella, S., Palmigiano, A., Piazzai, M., Tzimoulis, A., \& Wijnberg, N. M. (2017). Toward an Epistemic-Logical Theory of Categorization.EPTCS, 251, 167-186.https://doi.org/10.4204/ EPTCS.251.12

Goldstone, R. L., Kersten, A., \& Carvalho, P. R. (2018). Categorization and Concepts. In Stevens' Handbook of Experimental Psychology and Cognitive Neuroscience: Vol. Three (pp. 275-317). Wiley. https:// doi.org/10.1002/9781119170174.epcn308

Kristeller, P. O. (1951). The Modern System of the Arts: A Study in the History of Aesthetics Part I. Journal of the History of Ideas, 12(4), 496-527. https://doi.org/10.2307/2707484

Lotman, Y. M. (1977). The Structure of the Artistic Text. Translated from the Russian by Gail Lenhoff and Ronald Vroon. University of Michigan, Department of Slavic Languages and Literatures.

Lubart, T. I. (Ed.). (2018). The Creative Process. Perspectives from Multiple Domains. Palgrave Macmillan. https://doi.org/10.1057/978-1137-50563-7

Mattick, P. (2003). Art in its Time. Theories and Practices of Modern Aesthetics. Routledge Taylor \& Francis Group. https://doi. org/10.4324/9780203417836

Minda,J. P. (2015). The Psychology of Thinking. Reasoning, Decision-Making e Problem-Solving. Sage. https://doi.org/10.4135/9781473920262

Moulin, R. (1978). La Genèse de la rareté artistique. Revue d'ethnologie Française, 8, 241-258. 
Nisbett, R. E. (2005). The Geography of Thought. How Asians and Westerners Think Differently and Why. Nicholas Brealey Publishing.

Rivera, D. (1932). The revolutionary spirit in modern art. The Modern Quarterly (Baltimore), 6(3), 51-57.

Runco, M. A., \& Jaeger, G. J. (2012). The Standard Definition of Creativity. Creativity Research Journal, 24(1), 92-96. https://doi.org/10. $1080 / 10400419.2012 .650092$

Sawyer, K. (2006). Explaining Creativity: The Science of Human Innovation. Oxford University Press.

Shepard, R. N. (1987). Toward a universal law of generalization for psychological science. Science, 237, 1317-1323. https://doi.org/10.1126/ science.3629243

Shiner, L. (2001). The Invention of Art. A Cultural History. University of Chicago Press.

Walia, C. (2019). A Dynamic Definition of Creativity. Creativity Research Journal, 1-11.https://doi.org/10.1080/10400419.2019.1641787

Weiner, R. P. (2000). Creativity \& beyond. Cultures, Values, and Change. State University of New York Press. 